\title{
NPR2 Gene
}

National Cancer Institute

\section{Source}

National Cancer Institute. NPR2 Gene. NCI Thesaurus. Code C24637.

This gene plays a role in the mediation of transmembrane transport. 